University of Warwick institutional repository

This paper is made available online in accordance with

publisher policies. Please scroll down to view the document

itself. Please refer to the repository record for this item and our

policy information available from the repository home page for further information.

To see the final version of this paper please visit the publisher's website. Access to the published version may require a subscription.

Authors: Lydia Lewis

Title: $\quad$ Politics of Recognition: What Can a Human

Rights Perspective Contribute to Understanding Users' Experiences of Involvement in Mental Health Services?

Year of 2009

publication:

Link to http://dx.doi.org/10.1017/S1474746408004776

published

version:

Publisher None

statement: 


\section{Politics of Recognition: What Can a Human Rights Perspective Contribute to Understanding Users' Experiences of Involvement in Mental Health Services?}

\section{Lydia Lewis}

Department of Sociology, University of Warwick

E-mail: lydia.lewis@warwick.ac.uk

In the UK, participation in decision-making is increasingly being viewed as a right for users of mental health services. Yet research repeatedly finds a policy implementation gap in this area. Drawing on a localised, qualitative study involving three mental health service user/community groups, this article frames this issue in terms of a 'politics of recognition'. It demonstrates how whilst government user involvement policies officially attempt to recognise users and their voices, they simultaneously reconstitute failures of recognition in terms of status subordination and a disqualified identity for service users, thereby obstructing participatory parity and amounting to a dereliction of the core principles underlying human rights.

\section{Introduction: the policy context}

The active participation of the public and service users in influencing and shaping health, social care and other public sector services has been a cornerstone of social policy in the UK since the 1980s. In the healthcare sector, this 'user involvement' has been promoted across all levels of service interaction from individual service encounters through to service management and strategic planning both locally and nationally $(\mathrm{DoH}$, 2000, 2001a, 2005, 2006a and b, 2008; DHSSPS, 2004; SEHD, 2000, 2001, 2003a and b). Nowhere has this policy imperative been more salient than within mental health services (SO, 1997; DoH 1999, 2001b; DHSSPS, 2000; SEHD, 2006; CSIP/NIMHE, 2007) where a democratisation agenda has been strongly pursued by organised groups of service users/survivors ${ }^{1}$ (Campbell, 1999) and the voluntary sector has led the way in terms of practice development. In mental health services, then, the structures, forums and mechanisms that enable user involvement are numerous. They encompass NHS statutory patient and public involvement structures, including new Local Involvement Networks (LINks) in England, introduced as community-based forums designed to aid the responsiveness of health and social care services to local needs (DoH, 2006a, 2007a) and regional Health Councils in Scotland (SEHD, 2003c). They also encompass local and national service user/survivor groups and networks (both independent and serviceled), service users participating in policy-making and implementation groups and local or national user consultation exercises.

The aims of user involvement have been expressed in both consumerist terms of enhanced responsiveness to needs and democratic ones of service user empowerment and social justice. These aims do, however, remain a source of tension for user involvement 
since, whilst policies often conflate the two, it has been widely argued that meaningful participation for service users cannot be achieved through a consumerist approach that fails to engage with imbalances of power and divergences of interest between users and providers of services (e.g. Forbes and Sashidharan, 1997; Florin and Dixon, 2004; Stickley, 2006; Carr, 2007). Indeed, research across a range of sectors has repeatedly found an implementation deficit for user involvement policies (Bochel et al., 2007). In mental health services, this deficit appears to exist at both the individual level of treatment and care (Webb et al., 2000; Rose, 2001; Connor and Wilson, 2006) and the level of service planning and development (Wallcraft, 2003; Rutter et al., 2004; Hodge, 2005a; Carr, 2007). Evidence therefore suggests that in this service context, the aims of user involvement are still not fully realised in practice, and that, whilst there is some cultural change, this remains unaccompanied by structural transformation to afford users more decision-making power (Campbell, 2006). Furthermore, concurrent recent mental health policy imperatives towards increased surveillance and control of service users, which have included the introduction of new mental health legislation (SEHD Mental Health Division, 2003; DoH, 2007b) that extends the compulsory powers of services outside of in-patient treatment, appear incompatible with the development of user involvement, whether this emphasises 'choice' through consumerism or 'citizenship' through the democratisation of services (Pilgrim and Waldron, 1998; see also Carpenter, 2009 and Spandler and Calton, 2009 , both in this volume).

Alongside user involvement, the government has recently promulgated a human rights framework for healthcare $(\mathrm{DoH}, 2007 \mathrm{c})$ which promotes the application of human rights principles of dignity, equality, respect, fairness and autonomy as the value base for service provision. The application of this value base in public sector services is also being promoted through the work of the recently formed Equality and Human Rights Commission. This highlights the question of what the above state of affairs with user involvement in mental health services means for the achievement of a human rightsbased approach within these services. Indeed, effective user involvement is identified by the $\mathrm{DoH}$ as central in this approach to the development of mental health policy and services (ibid.; cf. Parker, 2007). This article draws on recognition theories and a qualitative study of user involvement in mental health services conducted in one British locality in order to explore this question. It aims to illuminate the social and cultural dynamics of user involvement in mental health services and associated human rights concerns, and to outline implications for policy development. Some theoretical background and then an outline of the study are presented first.

\section{Politics of recognition as a perspective on human rights}

Recognition theories are concerned with cultural or symbolic power and injustice, as analytically distinguished from, but related to, socio-economic injustice and political representation (Fraser, 1997, 2000, 2007; Lovell, 2007a). They are concerned with injustices 'rooted in patterns of representation, interpretation and communication' (Fraser, 1997: 14) and in 'cultural distinctions institutionalised in the status order' (Lovell, 2007a: 4), with 'discourses' and the ideological realm. Thus, those in disadvantaged positions, for example due to poverty (Lister, 2004) or a disabling society (Shakespeare, 2005), are seen to suffer both socio-economic injustices of deprivation and cultural ones of witheld recognition. Fraser $(1997,2000)$ identifies three dimensions to these recognition denials: 
non-recognition, the rendering of invisibility as a result of dominant cultural forms; misrecognition, being seen as lacking value and as inferior; and disrespect, being maligned or disparaged in everyday interactions or representations. A politics of recognition therefore aims towards seeing and valuing individuals, groups, identities, experiences, knowledges and expertise, (potential) contributions, humanity and personhood; upholding citizenship status and rights; and affording people dignity and respect (Fraser, 2000; Lister, 2004, 2007).

What is key here, then, is that the importance of recognition is not just sociopolitical but also personal, with a strong moral dimension to the issue (Honneth, 1995). Forms of non- or mis-recognition and disrespect can inflict harm and be personally damaging, undermining people's sense of selfhood and self-worth; they can be a form of oppression (ibid.; Taylor, 1992; Lister, 2004; Lovell, 2007a). A politics of recognition is thus concerned with both personal and social identities and the interaction between the two, and with the intersubjective shaping of subjectivity, or sense of self (Honneth, 1995). It is concerned with the personal value and meaning people give their own existence, lives and experiences. Non-recognition, it is asserted, can leave people with a diminished sense of self and mode of being, and mis-recognition and disrespect with a distorted one as they come to internalise the cultural or symbolic injustices of dominant understandings and values (Taylor, 1992). Struggles for social recognition are thus also struggles for selfesteem (feeling valued by one's social groups and society as a whole), self-respect (a sense of moral and legal personhood derived from the state) and 'self confidence' (emotional ontological security) (Honneth, 1995).

These intersubjective processes are central to Bourdieu's (1992) theory of symbolic power and practice. In his 'politics of recognition', power operates through the ways in which language and ideology come to construct social belief. This power of 'constituting the given', he argues 'can be exercised only if it is recognised, that is, misrecognised, as arbitrary' (Bourdieu, 1992: 170). Bourdieu terms the wielding of symbolic power 'symbolic violence', a form of domination and oppression which comes from constructing reality in ways that privilege the knowledge and culture of the dominant group, and through practices of social exclusion and inferiorisation. It operates through such constructions and practices being internalised by subordinate groups, as people may come to see their subordinate status as legitimate, through 'internalised oppression'. It is thus resisted through symbolic struggle to challenge the ideological basis of the social order - through recognising and exposing forms of domination for what they are, and asserting alternative meanings and values which afford dominated individuals and groups a higher social status and worth.

Recognition theories are often associated with the politics of 'new social movements' (e.g. Bourdieu, 1992; Honneth, 1995; Fraser, 2000; Fraser and Honneth, 2003) and discussed in relation to social policy, democracy and citizenship (e.g. Fraser, 1997, 2000; Williams, 1999; Lister, 2004). In these contexts, recognition is sought, on the one hand, for universal shared humanity for those who are socially marginalised or subordinated (Fraser, 2000), drawing on human rights principles such as the affording of respect and value to persons (Lister, 2004). Honneth (1995: 119) argues 'self-respect' to be derived from a 'sense of the possession of universal human rights' such as equality (in moral and legal terms). Accordingly, the recognition struggles of new social movements and service user groups have often been around 'personhood', common humanity and citizenship, and the related principle of equal moral worth (Fraser, 1999; Williams, 1999; Lister, 2007). On the 
other hand, recognition is also sought by some for cultural identity and experience and concerned with the revaluation of and esteem for groups (Fraser, 2000; Honneth, 2003), a recognition claim which can be related to the human rights principles of autonomy (or self determination) and dignity (Honneth, 1995; Dean, 2008). Both types of claim universality and distinctiveness ${ }^{2}$ - are inter-dependent with civil and political rights and social, cultural and economic rights. For instance, Fraser (2000) views the actualisation of full societal participation for subordinated groups as predicated upon their cultural revaluation - a claim which resonates with Cresswell's (2009) assertion in this collection that social and political rights are constituted by the assertion of 'experiential rights'. Similarly, Lister (2004) notes how socially derived respect and esteem are necessary for the full realisation of participation in public affairs, as a political right of citizenship (although she argues that the relationship here is in fact a dialectical one). Many theorists thus discuss cultural recognition, along with imbricated socio-economic 'redistribution' and political representation, as essential to the realisation of participatory parity in the public sphere (Honneth, 1995; Fraser, 1997, 2000, 2007; Fraser and Honneth, 2003; Lister, 2004; Lovell, 2007a), although the nature and direction of these relationships remain disputed.

In this light, this paper brings a range of recognition theories (cf. Lovell, 2007b), as a perspective on human rights, to bear on the study of user involvement in mental health services. Its focus is on the construction of identity and experience through the structures and relations of these services and how this relates to participation and equality. The article thereby addresses a gap in the substantive literature on user involvement in mental health services as well as in the application of recognition theories, which has tended to overlook the area of mental health, with more attention being paid to disability politics (e.g. Lister, 2007).

\section{The study}

The article draws on a localised, qualitative study of user involvement in mental health services conducted in the north-east of Scotland. The aim of the study was to explore the outcomes of user involvement policies for the participation of women and men service users within mental health services and for the development of these services. Various statutory and voluntary sector forums for user involvement had been established in the locality, including user representation on statutory sector planning committees, a user network attached to the psychiatric hospital, a user consultation exercise and a reference group administered by the voluntary sector. There were also several communitysector mental health groups established and run by users and ex-users of services. The study itself involved three of these mental health service user/community groups, sampled purposively according to their institutional affiliation and status: a statutory sector service user group, a voluntary sector community group (members of which included service practitioners and providers as well as users), and an independent mutual support group. The main purpose of the first group was to disseminate information about mental health services and activities in the locality and to feed users' views back to statutory service providers, whilst the second group took a stronger lobbying function with respect to mental health policy and services, and the third was primarily a support group but also made attempts to influence local mental health service provision at times. 
The study was conducted from a feminist critical discourse analytic perspective (Fairclough, 1992; Lazar, 2005), and so focussed on the constitution of power in and through language and other forms of social interaction. It accommodated a two-fold conception of discourse: as a way of understanding, or a set of ideas about a particular phenomenon, produced through language and social interaction that works ideologically in conjunction with other elements of social practice (Fairclough, 1992) (e.g. the discourse of 'mental illness'); and, since discourses are often associated with particular fields of social action and combine in particular ways, becoming core to the operation of social institutions, as 'knowledges' and the totality of interactions in a given field of social interaction (Fairclough, 2001) ('psychiatric discourse', for example).

The study also adopted a feminist methodological approach of a collaborative and 'interactive' mode of engagement with the groups and participants, and an actionorientation (Kelly et al., 1994) towards influencing policy and practice. Multiple research methods were employed, including: participant observation at group meetings; interviews and informal interactions with service users (female, $n=9$; male, $n=16$ ), practitioners $(n=2)$ and providers/policy-makers $(n=3)$; and analysis of local and national government policy documents. All interviews were recorded and transcribed, and data was analysed both thematically and discursively. ${ }^{3}$

\section{User involvement as recognition politics}

With the onset of user involvement, service users had become legitimate participants in the planning and development of mental health services in the locality. Officially, the policy initiative was touted as a measure to ensure recognition of service users and their (potential) contributions to service delivery, and the service users involved embodied the 'active' welfare subject thereby constituted (Williams, 1999), motivated by a desire to help themselves and others. Indeed, with growing acceptance of their increasing role, users' 'presence' and 'voice' were changing the cultural landscape of mental health services in the locale, and there were personal gains for service users, described mainly in terms of mutual support and opportunities for expression. However, the policy initiative simultaneously produced various failures of recognition, which in turn served to structure the social and political field of user involvement in mental health services in the study area. In achieving 'representation' for service users, then, user involvement had opened spaces within which recognition politics were played out (Fraser, 2007). In what follows, I discuss these politics along two themes: non-recognition and disrespect: being a 'user'; and misrecognition: the discourse of mental illness and issues of authority and credibility. These themes are related in the discussion to intertwined dimensions of redistributive and representative justice (Fraser, 2007).

\section{Non-recognition and disrespect: being a 'user'}

An intriguing finding of the study was how the policy discourse of user involvement itself had disempowering and derogatory effects, and as such was itself very much contested by service users in the locality. This was partly due to the 'involvement' element of the discourse working to delimit the degree of participation and influence afforded service users. However, invisibility for 'users' ${ }^{4}$ was encouraged by the policy discourse of user involvement itself, and its associated practices, being centred around people being users 
of mental health services and categorising people according to their type of mental health problem' (see Lewis, 2005; cf. Hui and Stickley, 2007). In the face of this, the mutual support group strove to operate outside of both the 'service user' construct and the illness schema and conceptions of psychiatric discourse. And for the community group, such concerns eventually led to the 'affiliation' column being deleted from the signing in form for meetings. Yet the fact that group members struggled in vain to find a satisfactory alternative term to that of service user revealed the narrow discursive and semiotic parameters within which they were operating. As the following participant notes, this meant that the practices of 'user involvement' inevitably had reductionist, homogenising and pathologising effects through positioning people primarily in terms of their relationship to services (Beresford, 2000) and their concomitant 'mental illness':

Even in places like the [named group], people who go along to that, you go along as a service user, and even though it's not meant, with the best will in the world people see you as a service user, because you wouldn't be there unless you had a mental illness. So even though they're trying to combat that, in a sense, what they're still seeing first is the mental illness ... [as opposed to] the women or the man or whatever; you know it seems to take centre stage. (Carol, $46-55$ years $)^{5}$

So as this participant observes, in the context of user involvement people became occluded from view by their 'mental illness' ascription and status as a 'welfare seeking being' (Hoggett, 2000). She notes how, in the field of mental health services, 'service user' as a discursive positioning constituted people in such a way as their 'mental illness' came to define them, along with the impossibility within the institutional confines of mental health services of eschewing culturally prescribed identities or of ideologically deinvesting these (Fairclough, 1992). The discourse and practices of user involvement consequently had their own marginalising and dominating effects through social practices of objectification (Foucault, 1982) which differentially marked 'users' from others in a hierarchical relation (Williams, 1999), and dividing practices (Foucault, 1982) in which some were deemed mentally ill and others were not - practices which support rather than help counter social exclusion whilst upholding the power and interests of psychiatry. These effects cannot help but be reconstituted in the course of user involvement, and, if internalised, can lead to selfalienation and oppression (Hoggett, 2000) - effects against which the above participant is clearly struggling (cf. Hodge, 2005b). Furthermore, this identity construction resulted not only in status subordination as people became constituted as less than full members of society (Fraser, 2003), but also a kind of dehumanisation through an intersubjective process in which people became denied 'wholeness' (as Cresswell, puts in his contribution to this volume) and thus full humanity. As such, 'service users' were prevented from participating in the (semi-)public arenas of user involvement as full-fledged partners on the grounds of both inequality of social standing (Fraser, 2003) and unequal endowment with the moral rights of 'the person' (Honneth, 1995).

These findings demonstrate how official movements towards valuing people and even attempts at universalist recognition can 'set in motion a second - stigmatising - recognition dynamic' (Fraser, 1997: 25). ${ }^{6}$ The above participant's reflections reveal the way in which 'user group' politics in healthcare have often centred upon 'claims for the realisation of personhood, for cultural respect, autonomy and dignity' (Williams, 1999: 673). Yet the very political alignments of user groups themselves work to simplify and reify group 
identities (Fraser, 2000), which 'act back upon their incumbents' (Taylor, 1998: 341) and to forestall mutual recognition (Crossley, 2004) and parity of participation (Fraser, 2003). In the context of mental health services, these effects are magnified by the stigmatising and all-defining nature of a 'mental illness' identity which it is impossible to positively assert (Hodge, 2005b; cf. Lister, 2004). Thus, through encouraging segregation and chauvinism, these dividing practices and resulting reification of 'mental illness' identities not only 'risk sanctioning violations of human rights' through constructing people as less than human, but also 'freezing the very antagonisms ... [they] purport to mediate' (Fraser, 2000: 108).

The 'stigma' associated with having a 'mental health problem' and with being a user of mental health services was consequently a ubiquitous concern for many participants, often requiring forms of identity management since, as one interviewee pointed out, 'nobody wants to be called a user'. Furthermore, many participants commented on the ideological and political effects of the 'user' construct itself. One female respondent commented, 'most genuine people don't use, they contribute', thereby indicating the ways in which the discourse constructed 'users' as deficient in certain respects (i.e. as failing to contribute) and therefore how it could work to undermine the value and efforts of individuals who became positioned as of unequal moral worth (cf. Fraser, 1997). Another male interviewee pointed out its implication in constituting relations of dependency as 'a "service user": it implies that you're addicted to them'. ${ }^{7}$ Consequently, this participant refused the 'user' construction through adopting a purportedly more 'respectable' 'patient' one. Others resisted it through using variations such as 'the user of the service' or else moved away from user involvement circles in order to dissociate themselves from mental health services or to adopt a more politicised 'survivor' identity.

These findings illustrate again how welfare identity categories and official policies aimed at recognition can have unintended consequences through which they produce their own injustices of recognition. They also illustrate how these identity categories have become a focus for resistance within the organising of many disability, service user and survivor groups, underpinned by demands for respect, autonomy and dignity (Williams, 1999). In the absence of a more fully developed and consensual social rights perspective in respect of welfare provision, the above participants were aware of how 'users' inevitably became 'construed as inadequate, blameworthy or undeserving' (Hoggett, 2000: 193), and that the construction of dependence was a means through which power was exercised (ibid.) and which was corrosive of citizenship rights (Lister, 2007). Moreover, these injustices of recognition could be highly personally damaging and distorting, reflecting back to people a 'confining ... demeaning ... and contemptible picture of themselves' (Taylor, 1992: 25), robbing people of 'every opportunity to attribute social value to their own abilities', and depriving them of self-esteem and self-realisation (Honneth, 1995: 134). Again, it was an awareness of this and the indignation, hurt and anger this produced which informed participants struggles against such recognition denials and the importance they attached to such struggles (Honneth, 1995).

The discourse and practices of user involvement thus had competing and contradictory effects, since they simultaneously worked to dominate, segregate and inferiorise 'users' and to open up spaces in which such hierarchical social relations could be contested and distinctions redrawn (Williams, 1999). As the following participant points out, however, the powerful subjectifying effects of service users' social positionings 
meant the balance of power was very much against them as they attempted to engage in such action:

For a lot of us it's been a hard struggle and a fight; we don't even believe in our own worth, to then start saying, 'hey, I can probably teach other people things', whatever it is, you know, total reversal of role, 'oh yeah I've got something to offer the world, I'm far from being a nobody, a nothing, a worthless waster' ... because society has put them in the position and they are unfortunately [pauses] wasting. I mean I'm saying that in the positive sense, you know, they are wasting, they could be doing a hell of a lot. (Mark, 46-55 years)

This participant clearly describes the reflexive constitution of personal and social identities (Fairclough, 1992), or rather of 'non-identities' (being a 'nobody') for service users. The extract provides an example of the way in which social movements have challenged the denial of basic human rights on the grounds of how witheld recognition denies self-respect and self-esteem, which is dependent not only on being valued by one's social groups, but also on experiencing oneself as 'valuable for society' (Honneth, 1995: 20). It illustrates well the injustice of misrecognition and internalised oppression (Bourdieu, 1992) for mental health service users who become constituted as dependent and helpless. It also illustrates how political action among mental health service users has, like that of feminism, been 'a struggle for cultural agency' (Lister, 2007: 160) and how forms of misrecognition can be both a social barrier and a motivating force for subordinated groups (Honneth, 1995: 120). Importantly in this context, the participant points out as well how, in being constructed by social institutions, the dependency and helplessness of many mental health service users is at least in part 'surplus' and potentially remediable (Fraser and Gordon, 1994; cf. Williams, 1999). The quote thus also indicates the inter-dependency between social structural change and the realisation of citizenship rights, on the one hand, and the cultural realisation of the principle of equal moral worth and the achievement of symbolic justice on the other (Fraser, 2000, 2007; Lister, 2004).

The ways in which these issues of status and self-esteem impacted on the achievement of participatory parity in user involvement fora (cf. Fraser, 2000, 2003; Lister, 2004) were evidenced by the research. At the first level, many participants, especially the women and a young male service user interviewed, described problems of 'confidence' about participating in group meetings, and especially in policy fora in which two women service users described feeling 'like a fish out of water'. Inequalities of class also impacted here; there was an over-representation of those from higher social classes in the groups, and especially among those holding 'user representative positions', and whilst some group participants were of working-class locations, it was clear that this disadvantaged their participation in respects. For example, at one policy meeting at which I was present, a round of introductions reached a male service user of an apparently working-class social location at which point rather than in introducing himself, he remarked awkwardly, 'I'm not really sure if I should be here' and went on to remain silent for the course of the meeting.

At a second level, there was the ubiquitous issue of the status of user groups in the field of mental health services and in wider society (cf. Honneth, 1995). On occasions when male psychiatrists addressed meetings of the groups, they tended to be allocated 'prime time' slots after which they departed, and there were times when user group members displayed deference towards service providers (who, for example, became thanked for 
their ten-minute attendance at a meeting). The following quotation demonstrates the pain and anger that injuries of status inequality, inferiorisation and misrecognition could invoke (cf. Honneth, 1995, 2003; Wilkinson, 2005), as well as Fraser's (2007: 20) point, that 'people can ... be prevented from interacting on terms of parity by institutionalised hierarchies of cultural value that deny them the requisite standing':

You're classed as some sort of under-dog, that's for sure (...) you only have to mention 'user groups' and 'network groups' and 'empowerment groups' and anything voluntary. If you haven't got a paid job, haven't got a title, then you're the under-dog. No matter how much you say you've got empowerment, you don't have it. (Maureen, 46-55 years)

This quotation illustrates once more how user involvement, as a policy initiative, could have unintended consequences of reinforcing a low social status for participants, since although user groups can afford those previously unrecognised some value, and create social worth and meaning for members, the social and self-esteem to be derived from this is counterweighted by subordination for such groups in the wider social and cultural order (Honneth, 1995). Through its participation in this order, and its being inescapably framed by dominant 'systems of signification and representation' (Lister, 2007: 161), which positioned participants as 'comparatively unworthy of respect or esteem' (Fraser, 2000: 114), user involvement thus simultaneously worked to reconstitute and reinforce an inferior, devalued and marginalised position for 'mental health service users' (ibid.; Lister, 2007; cf. Williams, 1999). From this perspective, user involvement was reproducing - and also masking - the violation of justice it was officially aiming to redress: status inequality between service users and other social actors in the mental health system.

Moreover, this research evidenced how there could be practices of subjugation within the activities of user involvement themselves. According with other research (e.g. Rutter et al., 2004), the accounts of statutory sector service providers tended to infantalise and patronise service users, constructing them in dialectical opposition to their own more 'mature' and 'reasonable' stance. For example, one made repeated reference to the need to involve 'appropriate individuals' who were 'able to work collaboratively', criticising both implicitly and explicitly the 'behaviour' of others who failed to take such an approach. Another referred to service users getting 'too involved' and finding it 'difficult' to adhere to the timeframe of meetings because 'they can only speak for so long'. Unsurprisingly, such subordinating constructions were often experienced as disparagement by service users, especially the men and those with professional backgrounds, one of whom commented:

Really, you have to burrow your way in and, if necessary, put up with all kinds of people you don't like, and go along with practices you don't like, and swallow quite a lot of insults as well. The earliest phase, when we first set up the 50/50 partnership was that anything we put down on paper should be in simple language that the users could understand - because we're all supposed to be stupid, you know. (Steve, 36-45 years)

This extract highlights yet again the competing and contradictory effects of practices in the area of user involvement, which could be aimed at affording people value through inclusiveness, but result in being 'insulting' to some. It illustrates an 'evaluative form of disrespect' or degradation in the sense of diminished social esteem or status, and how such attributions can be injurious to self-esteem, how experiences of social denigration or 
humiliation endanger the identity of human beings (Honneth, 1995: 134-5). It also demonstrates again how emotional responses from experiences of being disrespected and humiliated - indignation, anger, hurt - can provide the moral imperative and motivation for struggles for recognition (ibid; Honneth, 2003). Furthermore, whilst being particularly ironic and damaging in the context of mental health services, such necessary reactions to 'psychological and emotional wounds' themselves create their own wounds (Lister, 2007). Evidently, such situations left service professionals with a difficult balance to achieve, something also experienced by myself as I went about preparing and disseminating the research briefing paper for the study. This was particularly so as such discussions of 'appropriate language' and so forth for service users, referred to by the above participant, themselves work to constitute inequality due, as he notes, to the assumptions that underpin these.

The social-structural underpinnings of many of the claims of withheld recognition described above (Fraser, 2000) were thus omni-present and served to frame the interactions of the field. Participants' accounts were informed by an awareness of how they were socially positioned as mental health service users, and the intersections of this with their gender and class locations. Consequently, for those men 'not used to being subservient', as one put it, the recognition order and status hierarchy (Honneth, 2003) of mental health services in which psychiatrists were at the top and service users at the bottom was experienced as especially unjust and degrading. Many therefore engaged in forms of subversion and resistance to institutionalised relations and practices of social subordination (Fraser, 2000) whilst participating in user involvement activities. One participant, for instance, described how he 'dressed up' for meetings ('a radical approach with a clean shirt on'), a kind of presentation of self (Goffman, 1959) viewed as a means of symbolically challenging the status service users were prescribed. Moreover, through their accounts in the research and other discursive arenas, in the recognition of the operation of power, and through seeking to expose and understand this, participants were engaged in symbolic struggle - both personal and social (Bourdieu, 1992). Theirs was a struggle for recognition of power operating within ostensibly benign, helping relations and institutions and of the effects of this for the service users involved, a form of political resistance dependent on moral insight into injustice (Honneth, 1995) and of 'imaginative agency' (Hoggett, 2000) which afforded self-respect and self-esteem (Honneth, 1995). As I now discuss, these recognition struggles inevitably included battles against the constitutive work of the discourse of mental illness.

\section{Misrecognition: the discourse of mental illness and issues of authority and credibility}

Whilst user involvement has (ostensibly) been established as an attempt to value users' views and contributions, and there was limited expression and impression from participants in this research of deriving some personal value from taking part, their experiences were mainly described in terms of a sense of being devalued - or misrecognised - in the course of its activities. Indeed, in accordance with other research (e.g. Wallcraft, 2003; Connor and Wilson, 2006), there were complaints from service users about not feeling 'listened to' at all levels of interaction with services. At that of service planning and development, for example in the context of the treatment of a report of a local user consultation exercise, participants often referred to the difficulty of being 'taken seriously'. Evidently being used to such inferiorisation, for the women service 
users there was often a taken-for-grantedness about this, whilst, following the discussion above, two of the men participants explained the phenomenon as being due to a lack of institutional status and associated 'credibility', one pointing out that unlike that of many service users, my work had the benefit of 'academic respectability'. However, participants also implicated in this context matters of social identity in terms of [psychiatric] 'labelling', referring to the difficulty of asserting one's views, insofar as expressions of dissatisfaction, being upset, anger and so forth could become attributed to one's 'mental illness':

There's always, when you say something controversial, 'oh well she's not feeling very well at the moment' muttered under people's breath. (Carol, 46-55 years)

I mean, you can just write off users' views, you know, 'here he is being paranoid; here he is being depressed', you know, you can and that's it. (Chris, 36-45 years)

These extracts evidence the insidious workings of power within the field of user involvement in mental health services, which worked through psychiatric constructions not only undermining the authority and credibility of service users' views, but also individualising and pathologising these. Chiming with the discussions of Cresswell (2009) and Spandler and Calton (2009) in this collection, they illustrate the centrality of an 'illness' concept in producing these effects. However, they also indicate the gendered nature of these as whilst both women's and men's criticisms could be put down to 'depression', the men's concerns risked simply being written off as 'mad'. Such devaluing and discrediting, or 'psychiatric disqualification' (Lindow, 1991) can be understood as a form of symbolic violence towards service users (Crossley, 2004) who were battling for social recognition - of their views, their experiences, and indeed ultimately their humanity. The compelling injustice of this misrecognition as these struggles became turned back on the individual as a sign of their 'mental illness' or 'madness' was noted by the following participant in the context of discussing a long-standing dispute over the payment of his expenses for attending meetings:

I'm still the madman because I'm the one who's kicking up all this bloody fuss over one pound fifty. (Steve, 36-45 years)

This quotation illustrates well how distributive justice can be a form of recognition (Honneth, 1995) and is often linked to social status (Fraser, 2000), along with the cultural valuation of one's efforts (Honneth, 2003). It demonstrates how the withholding of such recognition can be experienced as a social injury and the emotional as well as political and moral significance of struggles for recognition (ibid.) - for personal and social worth and esteem, and for human dignity - in such economic confrontations (Honneth, 1995). From a human rights perspective, it also poignantly illustrates how the normative principle of being viewed as having 'rational insight' and a 'reasonable moral agent' (ibid.) which underpins our understandings of humanity, and therefore moral and legal legitimacy and the ascription of rights, is undermined when people are deemed 'mad' (Busfield, 2006; see also Spandler and Calton, 2009 this volume). Clearly, such undermining of one's personhood and humanity can work to have deleterious effects on interpersonal and therefore self-respect (Honneth, 1995). The denial of social recognition for this 
participant implies his moral degeneracy (ibid.; Honneth, 2003) and, following Honneth, his struggle is not only for economic redistributive justice and cultural revaluation, along with associated social status, but also for universalist humanity and incumbent interpersonal respect and self-respect.

This issue of moral responsibility being undermined by psychiatric discourse also manifested in the research in the theme of 'trust' - both social and personal. The above participant insisted in the context of his interactions with services that little would be gained unless workers could 'stop seeing people as sick people who can't be trusted'. Justice was for him, then, a matter not only of being afforded value, dignity and respect, but also of being recognised as a responsible moral agent of full integrity and common humanity (cf. Lister, 2007), of equal moral worth (Williams, 1999). Coinciding with Cresswell's (2009) discussion in this collection of the 'split experiential whole', the particular importance of this was illustrated by another female participant's account of the de-authorising effects of mental illness constructions on subjectivity 'to the point where you can no longer trust your own judgement'. Being denied universal recognition, then, being 'misrecognised', was to risk suffering not only 'an injury to one's identity' but also 'a distortion of one's relation to one's self' (Fraser, 2000: 109).

The subversive workings of psychiatric discourse, which could work to undermine service users' authority to speak and to act, were thus displayed here. Furthermore, the research illustrated the particular violence created when psychiatric discourse rubs up against an understanding of user involvement as conditional upon the advanced liberal 'individualistic ethic of self-responsibility' (Dean, 2008: 6). At one meeting, service users became castigated by a senior male psychiatrist for failing to take 'responsibility' for their own problems, whilst their 'dependency' became construed as behavioural, thereby serving to obscure the actual social construction of this dependency and struggles against this (Williams, 1999; cf. Connor and Wilson, 2006). In this manner, the discourse of psychiatry served to legitimate a denial of the right to participation. The extreme injustice of this in the face of the New Labour policy mantra of interdependent 'rights and responsibilities' of citizenship (Williams, 1999; Dean, 2008; Carpenter, 2009 this volume) was particularly striking, since these areas of moral jurisdiction became mutually denied to users of mental health services.

The symbolic injustice of 'psychiatrising' as a form of misrecognition in all of these contexts was evident from, and indeed amplified by, its repressive effects. It worked to silence service users, especially the women, in the public and semi-public arenas of user involvement: one woman confided that it had led her to decide against raising an issue at a meeting, whilst a male participant described how awareness of the matter among service users meant he was one of the few prepared to speak out, even though the consequent 'stress' of this could have deleterious effects on his own mental health. It also tied to a great deal of suppression of criticism in user involvement fora and in the formal research interviews - something attributed by one woman participant to a 'lack of self-esteem'. Furthermore, among the women, this suppression sometimes encompassed self-blame for problems experienced in interactions with services, and this seemed exacerbated by the effects of psychiatric discourse in personalising socially generated phenomena.

There were a variety of tactics through which people engaged in symbolic struggle in order to find an authoritative voice. These included discursive strategies such as the disciplining of language use so that qualifying or down-playing arguments were also at times a form of resistance and means of attempting to forge credibility, especially among 
the women, with the men tending to be more direct in their speech. There was also the male counter discourse of 'madness', used at times by the men to reclaim the deauthorising effects of a stigmatised identity and to pre-empt disqualification of their views. In addition, silence and refusal to participate in user involvement activities, and in the research, could have been understood in some cases as resistance, a refusal to subjectify oneself to dominant institutions, discourses and relations. Overall, however, the research evidenced how, rather than being challenged, the dominant cultural framework of psychiatry and its ideological and political effects became reproduced as well as reinforced in the context of user involvement, the discursive constraints of which left only limited space for subversion and resistance (cf. Hodge, 2005a; Stickley, 2006). Along with forms of non-recognition and disrespect, misrecognition as a result of the dominating effects of psychiatric discourse, and the discourse of mental illness in particular, thus also served to impede parity of participation in mental health service planning and policy-making fora for service users (cf. Hodge, 2005b) and thus to deny them full access in practice to their right to participation in this context (Honneth, 1995; Fraser, 2000, 2003; Lister, 2004).

\section{Conclusion}

In achieving representation for service users in the planning and development of mental health services, user involvement has 'furnished the stage' upon which recognition politics for service users is enacted (Fraser, 2007). Officially, the policy aims to afford value and worth to service users and their views and to help democratise service relations. However, this study demonstrated how, whilst the former of these aims has been partially achieved, recognition for service users is forestalled by the discourse and practices of user involvement, as tied to the discourse of mental illness and other elements of the wider discourse of psychiatry. Indeed, it simultaneously reconstitutes failures of recognition which act to structure the social and political field of user involvement in mental health services (Lovell, 2007a) in order to deny service users an equal voice (Lister, 2007). Consequently, user involvement fails to achieve participatory parity for service users, to achieve fair political representation for this group, and as such constitutes an unjust social arrangement (Fraser, 2003, 2007).

This research identified a two-dimensional failure of recognition for service users, which at the same time became the focus of symbolic struggle: status subordination (Fraser, 2000) and psychiatric disqualification (Lindow, 1991; Crossley, 2004). It also demonstrated how the social and cultural conflicts of the field over matters of identity and status (which also linked to socio-economic distribution) encompassed moral concerns for 'the person' (cf. Honneth, 1995, 2003). Indeed, service users' struggles were often underpinned by the principles of equal moral worth (Williams, 1999) and common humanity, and so were ultimately struggles for human rights. Yet as Orme (2002: 801) points out, 'rights should not have to be asserted by those with the least power'. Moreover, the research evidences the social dependence of access to rights in this context: the right to public participation could not be fully realised in practice without the cultural revaluation of service users' experiences and social recognition of service users as equal partners in interaction (Honneth, 1995; Fraser, 2000, 2003; Lister, 2004), without the actualisation of 'experiential rights' (Cresswell, 2009 this volume). Equality of participation would have in turn afforded people full humanity and allowed human rights principles of equal autonomy and moral worth to be respected (Fraser, 2003). As such, the current 
social and cultural framework of user involvement in mental health services and the incumbent systematic failure to recognise users' views and experiences, discussed by way of introduction and further evidenced by this study, amounts to a dereliction of the core principles underlying human rights: dignity, equality, respect, fairness and autonomy - principles which the government has proclaimed as the value base for healthcare $(\mathrm{DoH}$, 2007c).

The research also showed how the cultural dynamics and social ordering of user involvement in mental health services need to be understood in the context of the wider cultural and social-structural inequalities which include gender and social class. Yet the failure to achieve participatory parity for service users and associated rights violations are above all institutional harms which require institutional remedies at the level of mental health policy and services (Fraser, 2000). This study indicates that this institutional change needs to be two-pronged to address matters of both status and identity, and both structural and cultural in focus (Fraser, 1997).

Firstly, there is a need to challenge the current hierarchical relations which characterise mental health services and to work towards recognition of the status of service users as full partners in social interaction (Fraser, 2000, 2001; Lister, 2004). This will require a replacement of 'user involvement' policies and practices with those that explicitly address institutionalised power and inequality within mental health services at all levels of users' interactions with these (cf. Stickley, 2006). A core aim here should be changing 'institutionalized patterns of cultural value' which impede equal participation (Fraser, 2003: 218), and this can be facilitated by and through recognising, including through economic reward (Honneth, 1995), the informative and educational capacities and function of service user/survivor groups and organisations for policy and practice.

Secondly, and related to this since different valuations are underpinned by discourses (Fairclough, 1992; Lister, 2007), there is a need to rebalance mental health policy and services away from individualised and medicalised understandings of distress and associated responses, and towards a social model and community development approach built on humanistic principles and centred around people's social locations and associated life experiences (Newnes and Holmes, 1999; Coppock and Hopton, 2000; Tew, 2005). This would help destabilise 'mental illness' dichotomies and counter the dominating effects of psychiatric discourse which currently comes largely from the takenfor-grantedness of its schemas (Bourdieu, 1992). It would ensure people seeking help to overcome distress were afforded both social recognition (full societal membership) and universalist recognition (full humanity) (Fraser, 1999, 2003), working to unburden those so positioned of 'excessive ascribed or constructed distinctiveness' (Fraser, 2000: 115), of stigma. As a process of integration, for many it would be 'self alienation partially overcome' (Hoggett, 2000: 61). ${ }^{8}$

This psychological and political move will require cultural agency (Fraser, 1997; Lister, 2007) and an expansion of discursive contestation (Fraser, 1997) within debates about mental health policy and services, including on the part of service user groups, to ensure we all start thinking in more social and politicised terms about distress (see Lewis, 2009). It will also require a reframing of this political arena (Fraser, 2007) to include not just mental health workers and a 'subaltern counter public' (Fraser, 1997) of service users/survivors, but us all as citizens with an investment in mental health. Currently, user involvement suffers a political injustice of misrepresentation not only in terms of unequal participation for service users, but also misframing (Fraser, 2007) 
as 'users' become the containers for our fears about 'mental illness' (Hoggett, 2000). Redressing this will require a national public engagement strategy for mental health informed by a 'politics of differentiated universalism' (Lister, 1997) which recognises common humanity, citizenship and equal worth as well as the social inequalities and exclusions which frame people's lives (Williams, 1999; Lister 2007). This government strategy needs to encompass public concern through fora such as the new community LINks (DoH, 2006a) alongside the actions of service user/survivor groups, women's groups and other constituencies, as connected with social political action in other fields (Lewis, 2009).

Taken together, these measures can help realise the currently unfulfilled recognition aims of user involvement and concomitant human rights principles for healthcare $(\mathrm{DoH}$, 2007c) in the context of mental health, and indeed help safeguard the human rights of us all.

\section{Acknowledgements}

Thanks to all those who participated in this study and to two helpful reviewers for comments on an earlier draft of this paper. The study was funded by the MRC and the writing of this article by an ESRC/MRC Post-Doctoral Fellowship.

\section{Notes}

1 These terms indicate differing identities, with the term 'survivor' used to denote survival of both distress/illness and service usage, and 'service user' being less political.

2 In the mental health field, these two approaches have sometimes been described as 'normalisation' versus celebrating difference ('madness').

3 Ethical permissions were gained from Grampian Research Ethics Committee.

4 For stylistic reasons only, inverted comments are not always used when referring to 'users' or 'service users'.

5 Participants have been given pseudonyms. Transcribing conventions: ... indicates missing speech, italics emphasis, and square brackets added text or text changed for anonymity.

6 Fraser discusses these 'backlash injustices of recognition' (29) in relation to policies of affirmative economic redistribution. However, it is evident that policies such as user involvement, aimed at or suggestive of redistributing 'power' and affording social and cultural recognition, can also have this backlash effect.

7 Note here how particular types of discourse can come to be politically and ideologically invested in certain ways depending on their usage in different institutional settings or social domains (Fairclough, 1992) since such (stigmatising) effects do not necessarily arise from being a 'service user' in other settings (Rogers and Pilgrim, 1991).

8 On the relationship between challenging the dominance of bio-medical approaches to psychiatric practice and upholding human rights, see also Spandler and Calton's contribution to this collection.

\section{References}

Beresford, P. (2000), 'Service users knowledges and social work theory: conflict or collaboration?', British Journal of Social Work, 30, 489-503.

Bochel, C., Bochel, H., Somerville, P. and Worley, C. (2007), 'Marginalised or enabled voices? "User participation" in policy and practice', Social Policy and Society, 7, 2, 201-10.

Bourdieu, P. (1992), Language and Symbolic Power, Cambridge: Polity Press. 
Busfield, J. (2006), 'Mental disorder and human rights', in L. Morris (ed.), Rights: Sociological Perspectives, London and New York: Routledge.

Campbell, P. (1999), 'The service user/survivor movement', in C. Newnes, G. Holmes and C. Dunn (eds.), This is Madness: A Critical Look at Psychiatry and the Future of Mental Health Services, Ross-on-Wye: PCCS Books.

Campbell, P. (2006), 'Changing the mental health system - a survivor's view', Journal of Psychiatric and Mental Health Nursing, 13, 578-80.

Carpenter, M. (2009), 'A third wave, not a third way? New Labour, human rights and mental health in historical context', Social Policy and Society, 8, 3.

Carr, S. (2007), 'Participation, power, conflict and change: theorising dynamics of service user participation in the social care system of England and Wales', Critical Social Policy, 27, 2, 266-76.

Connor, S. L. and Wilson, R. (2006), 'It's important that they learn from us for mental health to progress', Journal of Mental Health, 15, 4, 461-74.

Coppock, V. and Hopton, J. (2000), Critical Perspectives on Mental Health, London: Routledge.

Cresswell, M. (2009), 'Psychiatric survivors and "experiential rights"', Social Policy and Society, 8, 3.

Crossley, N. (2004), 'Not being mentally ill: social movements, system survivors and the oppositional habitus', Anthropology and Medicine, 11, 2, 161-80.

CSIP/NIMHE (2007), Mental Health: New Ways of Working for Everyone, London: Department of Health.

Dean, H. (2008), 'Social policy and human rights: re-thinking the engagement', Social Policy and Society, 7, 1, 1-12.

DHSSPS [Dept. of Health, Social Services and Public Safety] (2000), Mental Health Services in Northern Ireland: VFM Review, Belfast: DHSSPS.

DHSSPS (2004), A Healthier Future: A Twenty Year Vision for health and Wellbeing in Northern Ireland, Belfast: DHSSPS.

DoH [Department of Health] (1999), National Service Framework for Mental Health, London: The Stationery Office.

DoH (2000), The NHS Plan - A Plan for Investment: A Plan for Reform, London: Department of Health.

DoH (2001a), Patient Representation in the New NHS, London: Department of Health.

DoH (2001b), The Mental Health Policy Implementation Guide, London: Department of Health.

DoH (2005), Creating a Patient-led NHS: Delivering the NHS Improvement Plan, London: Department of Health.

DoH (2006a), A Stronger Local Voice: A Framework for Creating a Stronger Local Voice in the Development of Health and Social Care Services, London: Department of Health.

DoH (2006b), Our Health, Our Care, Our Say, London: Department of Health.

DoH (2007a), The Local Government and Public Involvement in Health Act, London: Department of Health.

DoH (2007b), Mental Health Bill 2006-7, http://www.publications.parliament.uk/pa/pabills/200607/ mental_health.htm

DoH (2007c), Human Rights in Healthcare: A Framework for Local Action, London: Department of Health.

DoH (2008), Real Involvement: Working with People to Improve Health Services, London: Department of Health.

Fairclough, N. (1992), Discourse and Social Change, Cambridge: Polity Press.

Fairclough, N. (2001), 'The discourse of new labour: critical discourse analysis', in M. Wetherell, A. Taylor and S. Yates (eds.), Discourse as Data: A Guide for Analysis, London: Sage.

Florin, D. and Dixon, J. (2004), 'Public involvement in health care', British Medical Journal, 328, 159-61.

Forbes, J. and Sashidharan, S. P. (1997), 'User involvement in services - incorporation or challenge?', British Journal of Social Work, 27, 481-98.

Foucault, M. (1982), 'The subject and power', Critical Inquiry, 8, 777-95.

Fraser, N. (1997), Justice Interruptus: Critical Reflections on the 'Postsocialist' Condition, London: Routledge. 
Fraser, N. (1999), 'Social justice in the age of identity politics: redistribution, recognition and participation', in L. Ray and A. Sayer (eds.), Culture and Economy after the Cultural Turn, London: Sage.

Fraser, N. (2000), 'Rethinking recognition', New Left Review, 3, 107-20.

Fraser, N. (2001), 'Recognition without ethics', Theory, Culture and Society, 18, 2-3, 21-42.

Fraser, N. (2003), 'Distorted beyond all recognition: a rejoinder to Axel Honneth', in N. Fraser and A. Honneth, Redistribution or Recognition? A Political-Philosophical Exchange, London: Verso.

Fraser, N. (2007), 'Reframing justice in a globalising world', in T. Lovell (ed.), (Mis)recognition, Social Inequality and Social Justice: Nancy Fraser and Pierre Bourdieu, London: Routledge.

Fraser, N. and Gordon, L. (1994), "Dependency" demystified: inscriptions of power in a keyword of the welfare state', Social Politics, 1, 1, 4-31.

Fraser, N. and Honneth, A. (2003), Redistribution or Recognition? A Political-Philosophical Exchange, London: Verso.

Goffman, E. (1959), Presentation of Self in Everyday Life, New York: Doubleday.

Hodge, S. (2005a), 'Participation, discourse and power: a case study in service user involvement', Critical Social Policy, 25, 2, 164-79.

Hodge, S. (2005b), 'Competence, identity and intersubjectivity: applying habermas's theory of communicative action to service user involvement in mental health policy making', Social Theory and Health, 3, 165-82.

Hoggett, P. (2000), Emotional Life and the Politics of Welfare, Basingstoke and London: Macmillan Press.

Honneth, A. (1995), The Struggle for Recognition: The Moral Grammar of Social Conflicts (trans. Joel Andersen), Cambridge: Polity Press.

Honneth, A. (2003), 'Redistribution as Recognition', in N. Fraser, N. and A. Honneth, Redistribution or Recognition? A Political-Philosophical Exchange, London: Verso.

Hui, A. and Stickley, T. (2007), 'Mental health policy and mental health service user perspectives on involvement: a discourse analysis', Journal of Advanced Nursing, 59, 4, 416-26.

Kelly, L., Burton, S. and Regan, L. (1994), 'Researching women's lives or studying women's oppression? Reflections on what constitutes feminist research', in M. Maynard and J. Purvis (eds.), Researching Women's Lives from a Feminist Perspective, London: Taylor \& Francis.

Lazar, M. (2005), Feminist Critical Discourse Analysis: Gender, Power and Ideology in Discourse, Basingstoke: Palgrave Macmillan.

Lewis, L. (2005), 'User involvement within Scottish mental health policy: locating power and inequality', Scottish Affairs, 51, 79-107.

Lewis, L. (2009), 'Mental health and human rights: a common agenda for user/survivor and women's groups?', Policy and Politics (forthcoming).

Lindow, V. (1991), 'Experts, lies and stereotypes', The Health Service Journal, August, 18-19.

Lister, R. (1997), Citizenship: Feminist Perspectives, Basingstoke: Palgrave Macmillan.

Lister, R. (2004), 'A politics of recognition and respect: involving people with experience of poverty in decision-making that affects their lives', in J. Andersen and B. Sim (eds.), The Politics of Inclusion and Empowerment, Hampshire, Palgrave Macmillan.

Lister, R. (2007), '(Mis)recognition, social inequality and social justice: a critical social policy perspective', in Lovell, T. (ed.), (Mis)recognition, Social Inequality and Social Justice: Nancy Fraser and Pierre Bourdieu, London: Routledge.

Lovell, T. (2007a), 'Introduction', in (ed.), (Mis)recognition, Social Inequality and Social Justice: Nancy Fraser and Pierre Bourdieu, London: Routledge.

Lovell, T. (ed.) (2007b), (Mis)recognition, Social Inequality and Social Justice: Nancy Fraser and Pierre Bourdieu, London: Routledge.

Newnes, C. and Holmes, G. (1999), 'The future of mental health services', in C. Newnes, G. Holmes and C. Dunn (eds.), This is Madness: A Critical Look at Psychiatry and the Future of Mental Health Services, Ross-on-Wye: PCCS Books.

Orme, J. (2002), 'Social work: gender, care and justice', British Journal of Social Work, 32, 799814. 
Parker, C. (2007), 'Developing mental health policy: a human rights perspective', in M. Knapp, D. McDaid, E. Mossialos and G. Thornicroft (eds.), Mental Health Policy and Practice across Europe, Oxford: Oxford University Press.

Pilgrim, D. and Waldron, L. (1998), 'User involvement in mental health service development: how far can it go?', Journal of Mental Health, 7, 1, 95-104.

Rogers, A. and Pilgrim, D. (1991), "Pulling down churches": accounting for the British mental health users' movement', Sociology of Health and IIlness, 13, 2, 129-48.

Rose, D. (2001), Users' Voices: The Perspectives of Mental Health Service Users on Community and Hospital Care, London: The Sainsbury Centre for Mental Health.

Rutter, D., Manley, C., Weaver, T., Crawford, M. and Fulop, N. (2004), 'Patients or partners? Case studies of user involvement in the planning and delivery of adult mental health services in London', Social Science and Medicine, 58, 1973-84.

SEHD [Scottish Executive Health Department] (2000), Our National Health: A Plan for Action, A Plan for Change, Edinburgh: Scottish Executive.

SEHD (2001), Patient Focus and Public Involvement, Edinburgh: Scottish Executive.

SEHD (2003a), Sustainable Patient Focus and Public Involvement, Edinburgh: Scottish Executive.

SEHD (2003b), Partnership for Care: Scotland's Health White Paper, Edinburgh: Scottish Executive.

SEHD (2003c), A New Public Involvement Structure for NHS Scotland: Patient Focus and Public Involvement, Edinburgh: Scottish Executive.

SEHD (2006), Delivering for Mental Health, Edinburgh: Scottish Executive.

SEHD Mental Health Division (2003), An Introduction to the Mental Health (Care and Treatment) (Scotland) Act 2003, Edinburgh: Scottish Executive.

Shakespeare, T. (2005), 'Disabling politics? Beyond Identity', Soundings, 30, 156-60.

SO [Scottish Office] (1997), A Framework for Mental Health Services in Scotland, Edinburgh: Scottish Office.

Spandler, H. and Calton, T. (2009), 'Psychosis and human rights: conflicts in mental health policy and practice', Social Policy and Society, 8, 3.

Stickley, T. (2006), 'Should service user involvement be consigned to history? A critical realist perspective', Journal of Psychiatric and Mental Health Nursing, 13, 570-7.

Taylor, C. (1992), 'The politics of recognition', in C. Taylor and A. Gutmann, Multi-Culturalism and 'The Politics of Recognition', Princeton, NJ: Princeton University Press.

Taylor, D. (1998), 'Social identity and social policy: engagements with postmodern theory', Journal of Social Policy, 27, 3, 329-50.

Tew, J. (2005) (ed.), Social Perspectives in Mental Health: Developing Social Models to Understand and Work with Mental Distress, Philadelphia: Jessica Kingsley Publishers.

Wallcraft, J. with Read, J. and Sweeney, A. (2003), On Our Own Terms: Users and Survivors of Mental Health Services Working Together for Support and Change, London: The Sainsbury Centre for Mental Health.

Webb, Y., Clifford, P., Fowler, V., Morgan, C. and Hanson, M. (2000), “Comparing patients" experience of mental health services in England: a five-trust survey', International Journal of Health Care Quality Assurance, 13, 6, 273-81.

Wilkinson, I. (2005), The Impact of Inequality, London and New York: Routledge.

Williams, F. (1999), 'Good enough principles for welfare', Journal of Social Policy, 28, 4, 667-87. 